\title{
A BAÍA DE TODAS AS ÁGUAS: CONFLITO E TERRITORIALIDADE NAS MARGENS DO LAGO GUAÍBA
}

\author{
Rafael Victorino Devos ${ }^{1}$
}

A escassez mundial de água doce, a que é própria para o consumo humano, tem se destacado como uma das grandes problemáticas ambientais de nosso tempo. A partir de 22 março de 2005, a ONU estabeleceu a “Década da Água”, com o objetivo de, até o ano de 2015, promover a reversão da eliminação de mananciais e da deterioração da qualidade das águas planetárias, presentes à chamada “crise planetária da água” ${ }^{2}$. Segundo a ONU, uma em cada seis pessoas no mundo já enfrenta problemas de acesso à água potável e saudável.

As características naturais da água, como o fato dela não estar contida em fronteiras político-administrativas e ter sua qualidade relacionada a ecossistemas interdependentes que abrangem muitas cidades e mesmo mais de um país em uma mesma região hidrográfica ${ }^{3}$, desafiam governos, órgãos internacionais, empresas e cidadãos a novas formas de acordos pautados igualmente pela sua interdependência.

O destaque dessa problemática nos dias de hoje não se constitui como uma conseqüência natural da situação física em que se encontra o planeta, antes, ela se dá em meio ao que o antropólogo José Sérgio Leite Lopes chama de um processo histórico de ambientalização, de interiorização e naturalização de uma nova questão pública (Lopes, 2006, p.36). A preocupação com as condições do ambiente no qual vivemos vem se desenvolvendo através de transformações no Estado, com a produção

\footnotetext{
${ }^{1}$ Professor do Departamento de Antropologia e PPGAS UFSC, Pesquisador colaborador ao BIEV, Laboratório de Antropologia Social, PPGAS IFCH UFRGS.

${ }^{2}$ Entre os recursos líquidos, a água doce é minoritária no planeta. Segundo dados apresentados na Conferência da ONU para o Meio Ambiente e o Desenvolvimento, cerca de 97\% da água do planeta é salgada e imprópria para o consumo humano, sem tratamentos especiais, ainda muito caros. Apenas $3 \%$ das reservas mundiais de água são doces. Destas, cerca de 2,3\% estão armazenadas nas geleiras e nas calotas polares. Ou seja, somente $0,7 \%$ das reservas de água está no subsolo, lagos e rios.

${ }^{3} \mathrm{O}$ conceito de bacia hidrográfica refere-se à "área de drenagem de um curso de água ou lago" (glossário de hidrologia - http://webworld.unesco.org/water/ihp/db/glossary). Em hidrologia, a região hidrográfica é formada por diversas bacias que escorrem para um corpo de água único, como o Lago Guaíba. No entanto, a idéia de região abrange não só a rede hidrográfica física, ou seja, o conjunto de rios e outros cursos de água, lagos e reservatórios em determinada região, mas igualmente as unidades político-administrativas implicadas nos territórios importantes ao ecossistema da bacia hidrográfica em questão.
} 
de leis, normas e de novas construções institucionais, mas também através de transformações nas visões de mundo e no comportamento das pessoas.

Essas novas elaborações institucionais e jurídicas, no Brasil e em outros países ganham destaque em ações sociais, em pesquisas e em projetos internacionais como o gerenciamento de bacias hidrográficas ou o caso da criação e desenvolvimento do Parque Estadual Delta do Jacuí, que será aqui comentado. No entanto, pouco se tem pesquisado as transformações nas formas como as pessoas passam a encarar o ambiente em que vivem e na maneira como passam a se relacionar com ele, sobretudo no meio urbano, pois essa crise planetária é tomada como um fato, e não como uma construção social.

Seguindo uma tradição de pesquisa antropológica em meio às Sociedades Complexas Contemporâneas, que no Brasil se constitui enquanto uma Antropologia Urbana, pode-se afirmar que essa reorientação de comportamentos, de transformação de estilos de vida em meio às transformações da paisagem urbana do mundo contemporâneo não ocorre de uma mesma maneira e numa mesma direção. Conforme o antropólogo Ruben Oliven (1995), o processo histórico de urbanização desencadeia tendências gerais de reorientação de práticas cotidianas e visões de mundo, como a própria preocupação com a qualidade do meio ambiente, mas essas reorientações só se efetivam de forma heterogênea e dinâmica, multiplicando a diversidade de formas de viver e de se pensar como cidadão urbano.

Pesquisando o tema da memória coletiva e do cotidiano junto aos moradores de um bairro inserido em uma reserva ambiental, as ilhas do Bairro Arquipélago, no Parque Estadual Delta do Jacuí, em Porto Alegre, RS, pude investigar como esse processo de ambientalização se desenvolve em meio à trajetória desses moradores, como ele é narrado em meio à sua história de vida e qual sua importância na elaboração das representações desses moradores sobre o ambiente em que vivem (Devos, 2007).

Este artigo retoma parte de minha pesquisa de doutorado (Devos, 2007), situando a cidade de Porto Alegre em meio aos debates mundiais sobre a escassez de água doce no planeta. Tem como objetivo esclarecer como a questão ambiental tensionada pelos usos e cuidados com a água permite uma abordagem diferenciada da territorialidade urbana, ao situar determinados territórios urbanos atravessados por diferentes esferas éticas no contexto de uma bacia hidrográfica. Ao mesmo tempo, pretendo demonstrar como a temática dos conflitos de uso da água têm a força 
socializadora de agregar muitas outras dimensões éticas da vida na cidade, e no caso do Delta do Jacuí, estão já colocados na trajetória política das comunidades que ocupam as ilhas.

Para tal, apresentarei alguns dados relativos ao evento Romaria das Águas realizado em 2003, a narrativa de uma interlocutora de pesquisa, e evocarei algumas publicações resultantes do Fórum Internacional das Águas, realizado em 2003 e 2004 na cidade, assim como publicações relacionadas à política ambiental, em especial, à política internacional de recursos hídricos. Outras observações serão pontuadas, quanto a outros eventos, manifestações e situações em que pude acompanhar a dimensão política da questão da ocupação do solo e das águas do Delta do Jacuí.

\section{Meio ambiente na macro-esfera}

O Fórum Internacional das Águas, realizado em Porto Alegre em 20034, reuniu cerca de 2.200 participantes que, durante três dias, assistiram a oficinas e conferências ministradas por autoridades nacionais e mundiais no assunto água.

Boa parte dos 2.200 participantes do Fórum era composta por estudantes ou profissionais de áreas técnico-científicas relacionadas ao meio ambiente. Debatiam-se projetos políticos e concepções diversas sobre formas de gestão pública da água, resultando na I e na II "Carta de Porto Alegre", documentos elaborados a partir das discussões das duas primeiras edições do Fórum, a serem publicadas e inseridas em outros fóruns e espaços internacionais de debate do tema ${ }^{5}$, propondo uma forma de gestão pública da água de maneira "sistêmica (contemplando os usos múltiplos), descentralizada (tendo a bacia hidrográfica como unidade), participativa (com integração de todos os atores sociais) e baseada no planejamento" ${ }^{\text {. }}$.

A questão da água unia tanto demandas ecológicas, como os debates sobre o aquecimento global do planeta, a preservação da flora e fauna de unidades de conservação ambiental do Estado, a questão dos agrotóxicos e do lixo das cidades, quanto outras demandas, como as disputas do campo religioso pelo uso dos espaços públicos para celebrações religiosas, e a questão da moradia urbana, no caso, a

\footnotetext{
${ }^{4}$ Na análise privilegiarei a edição de 2003, embora o Fórum das Águas venha se repetido todos os anos na cidade.

5 Carta de Porto Alegre - Fórum Internacional das Águas 2003. Disponível em http://www.onuportugal.pt/body_ano_internacional_da_agua_doce.html, último acesso em 13/10/2005. ${ }^{6}$ idem.
} 
ocupação das chamadas áreas de risco nas cidades por classes populares, como é o caso da ocupação das ilhas de Porto Alegre.

Em suas atividades paralelas, o fórum reunia também associações comunitárias, entidades religiosas, ONGs ambientalistas, escolas, clubes esportivos, que reivindicavam outras questões sob a bandeira da água. Promoveram-se trilhas ecológicas nas nascentes dos rios, exposições de trabalhos escolares de educação ambiental, oficinas, shows de música. O evento encerrou-se com a Romaria das Águas, que unindo ecologia e religião, levou gente de todo o Rio Grande do Sul a navegar pelas águas do Lago Guaíba acompanhando uma imagem de Nossa Senhora Aparecida, terminando com a celebração à beira do lago das energias e entidades protetoras das águas. Haviam diversos cultos e fiéis presentes, em que se destacavam os devotos das religiões afro-brasileiras, pelo número de devotos que cultuavam a Mãe Oxum, senhora das águas doces.

O objetivo do evento em 2003, e da sua segunda edição em 2004, foi o de expandir o público da Romaria das Águas que já ocorrera em outros anos, para mobilizar autoridades políticas, técnicos, empresários e a população em geral de Porto Alegre e de outras cidades do Estado do Rio Grande do Sul quanto à importância de uma gestão pública da água, face à sua escassez na realidade mundial.

O tema da ética ambiental, em especial quanto ao uso da água, reunia nesse evento, sob uma nova ótica, questões éticas presentes à vida urbana, com relação às diferentes concepções de bem público e, portanto, dos direitos e deveres com relação a estes, sejam eles os espaços públicos (como a orla dos rios enquanto solo urbano), sejam os elementos da natureza, como a água, que perpassa e liga territórios urbanos, simbolizada em suas múltiplas entidades protetoras.

Pretendo investigar, nesse texto, como pode ser pensada essa realidade da escassez mundial de água doce, ou seja, sob qual ponto de vista essa realidade é construída, e quais questões são colocadas a partir dos debates em torno dos conflitos de uso da água, que forneceriam outra abordagem para os conflitos de uso e ocupação do Delta do Jacuí enquanto território entre o natural e o urbano.

Justamente, seguindo a abordagem de Simmel (1984, 2004) sobre o conflito, cuja força socializadora agrega e rearranja indivíduos e grupos sociais em torno de um objeto em comum, esta abordagem nos permite investigar como a própria questão do meio ambiente, ou da escassez das águas se transforma e se constitui nessa dinâmica do conflito. Seguindo os ensinamentos de uma antropologia das chamadas sociedades 
complexas, ou dos estudos sobre as inter-relações entre o local e o global, sabe-se que essas grandes tendências mundiais de reorientação das representações sociais e das ações cotidianas não se realizam senão de forma localizada, e diferenciada.

Enquanto tratamos do ambiente no sentido afirmado da macro esfera ética, da que se refere ao planeta como um ambiente em comum para todos os seres humanos, poderíamos dizer que ele está situado dentro do que Luc Ferry (1994) propõe para pensar a ecologia para além de uma ciência, enquanto uma ideologia contemporânea ${ }^{7}$. Segundo Ferry, a visão sistêmica que a ecologia propõe reataria, do ponto de vista filosófico, com uma visão da existência de uma ordem cósmica em que um "contrato natural” se impõe entre os homens e os demais seres vivos (Ferry, 1994, p. 18).

Afirmando uma nova ordem moral ao universo, a da recuperação de uma harmonia perdida com as forças da Vida, os chamados movimentos ecológicos, representados politicamente por $\mathrm{ONG}^{\prime}$ s internacionais ${ }^{8}$, dirigem uma mesma política a todos os cantos do planeta: a interdição de práticas econômicas que atentam contra a biosfera $^{9}$ (como a caça, a pesca industrial predatória, o desmatamento) e a promoção de novos costumes dotados de uma nova consciência capaz de rever o Processo Civilizador da Civilização Ocidental ${ }^{10}$.

A ecologia, tanto em sua vertente ideológica mais “antropocentrista”, a que se preocupa no final das contas com a sobrevivência da espécie humana, quanto em sua vertente "biocentrista” mais profunda (Ferry, 1994, p. 22), que coloca a sobrevivência do ecossistema acima da sobrevivência da espécie, apontam para o mesmo ser humano e um mesmo cosmos em sua visão sistêmica. A relação que essa tendência de “ecologização do mundo social”11 estabelece entre macrocosmo e microcosmo extrapola, conforme nota Michel Maffesoli (1996), o domínio das políticas públicas e ações institucionais, para evidenciar-se igualmente em outras dimensões sociais, como a moda, o lazer, em que a experiência de partilhar o mesmo meio ambiente é difundida entre determinados estilos de vida urbanos. Essa revisão crítica do trajeto de

\footnotetext{
${ }^{7}$ Portanto, não estou me referindo à Ciência da Ecologia e seus pressupostos neste trabalho, mas sim à dimensão moral e ética que a questão passou a ter no mundo contemporâneo, para a qual a abordagem do filósofo Luc Ferry (1994) se apresenta como mais apropriada pelas inter-relações que o autor estabelece entre uma "cultura democrática" do Ocidente com o pensamento ecológico.

${ }^{8}$ Alguns exemplos conhecidos são as ONG's internacionais Greenpeace (www.greenpeace.org), o Seashepherd (www.seashepherd.org) e o WWF (www.wwf.org).

9 "O ecossistema - a 'biosfera' - é investido, portanto, de um valor intrínseco muito superior ao dessa espécie, afinal de contas muito mais nociva, que á espécie humana.” (Ferry, 1994:24)

${ }^{10}$ Ver a obra de Norbert Elias, em especial, O Processo Civilizador, vol. I e II. (Elias, 1990 e 1993)

${ }^{11}$ Refiro-me à expressão proposta por Michel Maffesoli em seu livro intitulado "No fundo das aparências” (Maffesoli, 1996:239)
} 
dissociação Homem/Natureza, essa ordem moral que pretende se estender a todas as populações do planeta traz consigo o pressuposto de que todos os seres humanos, enquanto espécie, vivem de uma mesma maneira, consumindo a mesma água e o mesmo combustível, produzindo o mesmo lixo e tendo a mesma visão de Natureza para além dos limites do universo artificialmente construído pela humanidade.

A “sociedade ocidental enquanto cultura” (Sahlins, 2003, p. 166) já teria por demais assimilado a "qualidade de vida" ambiental ao seu sistema de valores como bem de consumo que promove o "bem estar" (Sahlins, 2003, p. 169), enquanto uma continuidade do que marca a cultura democrática. Segundo Ferry (1994), trata-se do elogio do desenraizamento, da “solidão bem dosada” (Ferry, 1994:28), fundamentais para a liberdade do indivíduo em sua experiência urbana. A busca dessa harmonia perdida entre os seres humanos e a Natureza não é proposta através do retorno à vida simples (ainda que comunidades indígenas, de pescadores, de agricultores ecológicos sejam muitas vezes reverenciados como "ecólogos natos" pelos movimentos ecológicos), mas da continuidade desse desenraizamento em direção a um enraizamento planetário, inserido em uma nova ordem global e cosmopolita.

Embora essa nova ordem ecológica possa ser pensada como uma tendência geral, ou seja, no sentido da chamada “Cultura Global” (Featherstone, 1994), para que possa ser investigada do ponto de vista da Antropologia, e não da Filosofia ou do Direito, precisamos entendê-la como um processo de globalização, que guarda particularidades em suas interações localmente situadas. É preciso levar em conta a dimensão ética das interações globais em que as políticas ambientais são elaboradas, na medida em que há muito tempo a questão da preservação do meio ambiente em que se vive deixou de pautar apenas discursos ideológicos para fazer parte das disjunções contemporâneas entre economia, cultura e política (Appadurai, 1994).

Historicamente, aponta-se a Conferência das Nações Unidas sobre Ambiente Humano de Estocolmo, realizada na Suécia em 1972, como o início dos debates em escala mundial sobre a preservação do meio ambiente. Na conferência opunham-se dois pontos de vista, um mais próximo da chamada ecologia profunda, a qual se refere Luc Ferry (1994), composta por intelectuais e ativistas de países europeus que defendiam a tese do “crescimento zero” e da inovação tecnológica para frear tanto o crescimento populacional da humanidade quanto seu processo de desenvolvimento industrial predatório e poluidor. O segundo ponto de vista era defendido por países ditos sub-desenvolvidos, ou periféricos, que defendiam seu direito ao crescimento 
industrial, em que industrialização significava mais progresso e crescimento econômico (Basso, 2004).

Tais pontos de vista teriam se unificado sob o conceito de "desenvolvimento sustentável”, que reúne o combate à fome à luta pela preservação da Natureza em um mesmo compromisso com um "futuro comum" da humanidade. O conceito já era dominante na chamada II Conferência Mundial para o Meio Ambiente e Desenvolvimento, a Eco-92, realizada no Rio de Janeiro, em 1992, reunindo 114 chefes de Estado, 10 mil jornalistas e 40 mil militantes de 3.200 ONGs (Basso, 2004). A Agenda 21, documento produzido pelo encontro, prevê uma série de estratégias globais de desenvolvimento sustentado, que acrescentam às soluções tecnológicas da chamada indústria limpa (reflorestamento, filtros, combustíveis alternativos) soluções no campo do planejamento urbano (articulando as questões de saneamento, coleta e destinação do lixo, abastecimento) e principalmente do Direito, dando força ao campo da legislação ambiental, que lida com as questões de indenizações, multas, penalidades à empresas e cidadãos que atentam contra a qualidade do meio ambiente $^{12}$.

Esse processo histórico, entendido por José Sérgio Leite Lopes (2004; 2006) como "ambientalização" de conflitos sociais, como internalização de uma nova questão pública, desdobra-se no Brasil na produção de leis e normas e na construção institucional (Lopes, 2004) de secretarias do meio ambiente em nível federal e estadual, agências e conselhos de controle ambiental, e outras instituições que abrem espaço para profissionais diversos como engenheiros sanitaristas, juristas, profissionais de saúde pública, economistas e posteriormente, geógrafos, biólogos e arquitetos (Lopes, 2006). Nas escolas ocorre o processo de interiorização de comportamentos e práticas através da promoção da educação ambiental, na atividade escolar ou paraescolar, comportando formas de difusão por meios de comunicação de massa (Lopes, 2006). Surgem novas áreas jurídicas com destaque para a categoria de direitos difusos, a idéia de direito coletivo, e da necessidade de reprodução da qualidade de vida de uma geração para outra, de sustentabilidade. Nas empresas, desenvolvem-se os selos de qualidade ambiental como forma de normatização do processo de produção (Lopes, 2006). Na sociedade civil organizada (associações,

\footnotetext{
${ }^{12}$ A chamada área de Direito Ambiental guarda peculiaridades que desafiam um sistema jurídico baseado na propriedade, seja privada ou pública, na medida em que a água e o ar, por exemplo, são bens que não se enquadram nas mesmas categorias que o solo. Cf. Soares, 2003.
} 
sindicatos) os assuntos ambientais aparecem transversais e conexos a outras questões que envolvem a qualidade de vida, apropriados criativamente (Lopes, 2006).

Contemporaneamente, em um contexto de globalização, são inúmeros os fundos internacionais de financiamento e as ONGs internacionais que defendem a preservação dos rios, das matas, dos animais em todos os cantos do planeta. Não se trata simplesmente do crescimento do sentimento de compaixão com seres vivos nãohumanos, ou da generalização de conhecimentos de Biologia entre os seres humanos. O alcance global desses movimentos precisa ser antes compreendido pela própria dimensão global que adquiriram as interações entre instituições, cidadãos e governos no mundo contemporâneo. A imagem do mundo como uma aldeia global não é apenas uma conseqüência do desenvolvimento da tecnologia de telecomunicações, ou da complexificação da economia transnacional. O ambiente planetário não se constrói apenas por conceitos científicos como ecossistema, mas em paisagens e comunidades imaginadas (Anderson, 1983) no campo da cultura, num jogo de pertencimentos e identificações de determinados grupos sociais com determinadas regiões do planeta.

Inúmeros autores nas Ciências Sociais ${ }^{13}$, e em especial na Antropologia, apontam para as inter-relações que se estabelecem entre o local e o global, entre o nacional e o regional, como fundamentais para o jogo de identidades do mundo contemporâneo. Ruben Oliven (1992) demonstra como a identidade local, ou regional, só pode ser pensada em relação a identidade nacional, ou transnacional. Entre os emblemas que compõem essa “invenção de tradições” nacionais que consolidaram os atuais Estados modernos, unificando sociedades e culturas através de representações sociais em comum, estão justamente paisagens idealizadas, que adquirem significado do ponto de vista de uma memória social para a sociedade nacional ou regional como um todo ${ }^{14}$.

Um primeiro momento da política de proteção ambiental dos ecossistemas terrestres é apontado como tendo surgido dessa articulação entre Nação e Estado através de determinados territórios, pedaços de natureza considerada selvagem, que deram origem aos Parques Nacionais e Estaduais enquanto paisagens-símbolo da Nação. É uma tendência, chamada wilderness ${ }^{15}$, de conservação da Natureza, tomada como intocada e intocável, transformada em natureza espetáculo, testemunho da

\footnotetext{
${ }^{13}$ Cf. Featherstone (1990) e Arizpe (2001).

${ }^{14}$ Cf. Halbwachs (1990) e Oliven, 1992:20.

${ }^{15}$ Cf. Ferry (1994), Diegues (2000 e 1996) e Schama (1996)
} 
natureza original do solo nacional e dos valores de uma comunidade idealizada dos antepassados que teriam erguido os pilares da cultura nacional ao enraizarem-se em solo virtuoso. Tal tendência se origina efetivamente tanto nos Estados Unidos quanto na Alemanha nazista (Ferry, 1994), tendo suas origens ideológicas ligadas ao Romantismo do século XVIII. Com o desenvolvimento da Ciência Ecológica, essa tendência teria se aliado à chamada "Ecologia Profunda" (Ferry, 1994) na década de 1970 e, contemporaneamente, à Biologia da Conservação (Diegues, 2000), correntes científicas dominantes nos atuais modelos globais de preservação da natureza, que propõem a separação de áreas naturais das atividades humanas em geral, reservando determinados territórios para a renovação da flora e da fauna local, transformando a biodiversidade local em patrimônio da humanidade, e portanto, acima dos interesses econômicos locais e internacionais.

Inúmeros conflitos eclodiram em países como a Índia, o Brasil, e em países africanos gerados pela remoção efetiva ou pela tentativa de remoção de populações consideradas tradicionais como grupos indígenas, comunidades de pescadores artesanais, de seringueiros, de ribeirinhos, de quilombolas, de extrativistas em geral, que tiram seu sustento do meio em que vivem e que passaram a ter seus direitos defendidos na medida em que realizariam um manejo histórico de suas paisagens locais, com saberes localmente construídos a serem preservados juntamente com o ambiente (Diegues, 2000), pois são tomados como parte da etnobiodiversidade (Diegues, 2000) local.

Neste sentido, a questão ambiental, de forma conflitiva, mesmo valorizando a diversidade dos saberes e práticas culturais com relação aos ambientes, promove a inserção de tais comunidades em esferas sociais mais abrangentes na política internacional ambiental, articulando práticas locais aos mercados internacionais como o turismo, a comercialização de arte/artesanato, o registro de patentes sobre usos de plantas medicinais, nas negociações e fluxos de mercadorias, de pessoas, de informações do processo de globalização.

Em termos éticos, o conhecimento científico que foi necessário para gerar toda a tecnologia industrial difundida mundialmente, é igualmente responsável pela revisão das conseqüências éticas da transformação das relações das sociedades humanas com o meio ambiente como um todo. Não é apenas o conhecimento da estrutura física do planeta que está implicado na perspectiva ambiental, mas também a territorialidade, tem um papel igualmente fundamental na investigação de quais 
arranjos sociais entre grupos sociais diversos estão expressos e ao mesmo tempo mediando as relações entre os indivíduos e o meio natural.

Na Antropologia, desde os estudos de Mauss e Durkheim $(1981,1989)$, sabe-se que na relação dos diferentes grupos sociais com a Natureza (e com o sobrenatural) estão expressas as relações sociais desses grupos no seu interior e com os demais grupos à sua volta. No meio ambiente, entendido como espaço simbolicamente vivido e representado, estão colocadas as fronteiras simbólicas pelas quais transitam redes de relações diversas, onde estão situados domínios diversos da vida cotidiana. São essas fronteiras e representações sociais sobre os ambientes onde vivem, re-elaboradas a partir das interações sociais, que são importantes de serem discutidas, na medida em que a Biosfera é também uma representação, uma imagem do mundo, que se pretende absoluta, mas que é ao mesmo tempo redesenhada em meio aos debates e conflitos mundiais sobre a preservação do planeta, quanto adquire significados diversos quando é localmente interpretada.

Essas novas paisagens que se apresentam no mundo ecologizado aproximamse do que Appadurai (1992) desenvolve em sua teoria dos scapes $^{16}$ (panorama na tradução brasileira). Appadurai investiga a Cultura Global como fluxos: fluxos de mercadorias, de pessoas, de finanças, de imagens, de tecnologia, que conformam os panoramas, os scapes a que se refere. São "mundos imaginados”, paisagens que só podem ser apreendidas em movimento, na medida em que as disjunções entre Nação, Etnia e Estado conformam esses espaços simbólicos diferenciados em que as cidades passam a estabelecer conexões inesperadas, como as comunidades de migrantes que mantêm comércio constante com seus espaços de origem, ou que consomem as imagens de uma comunidade de origem imaginada, ao deslocarem-se pelo mundo dos grandes negócios globais. São nesses "pontos nodais” que as imagens dos paraísos terrestres do turismo são consumidas, que os encontros internacionais de debate sobre o ambiente são realizados, que a Natureza é de alguma forma retomada no ambiente artificialmente constituído pela Civilização Industrial Moderno-Contemporânea.

É o compromisso com essa paisagem do mundo globalizado em questão que está em jogo nos acordos internacionais. Estas demandas, que se estendem a todas as áreas do planeta, urbanas e não-urbanas, trazem consigo o pressuposto de uma visão

\footnotetext{
${ }^{16}$ Embora na tradução brasileira o termo scape tenha sido traduzido para "panorama", em sua denominação original, há uma proximidade com o conceito de paisagem na língua inglesa, landscape, a partir do qual o autor investiga os fluxos da cultura global.
} 
sobre a Natureza a partir da Cidade. Trata-se um ponto de vista sobre as relações entre homem, sociedade e ambiente que leva em conta a interdependência dos grupos humanos nas diferentes esferas sociais - locais, regionais e globais - enquanto habitantes de um mesmo e generalizado ambiente, o Planeta Terra. A chamada “questão ambiental”, é portanto uma forma de interpretação do trajeto de dissociação Homem/Natureza, e uma preocupação próxima a "vida mental da metrópole" (Simmel, 1979), na medida em que demanda um deslocamento do sujeito para pensarse a si mesmo como "um elo em uma enorme organização de coisas e poderes" (Simmel, 1979, p. 21).

A adoção de uma postura responsável, de um enraizamento cósmico a nível planetário, em direção a um comportamento ambientalmente comprometido se apresenta como mais uma tendência geral de reestruturação de relações sociais e orientações culturais que, no entanto, é diferencialmente experienciada pelos grupos sociais. O desafio da construção de uma “ética global”, que tem sido proposta por órgãos internacionais de proteção ambiental, tem como pressupostos determinados saberes não apenas de cunho técnico-científico, como noções de saneamento e do conceito de ecossistema, mas igualmente pressupõe uma determinada experiência, que defendo aqui, é próxima da experiência urbana.

Esse ambiente urbano não se refere ao espaço construído da cidade em si, mas à forma como os sujeitos sociais tomam posse desse espaço, como o reconhecem, enquanto ambiente técnico-cultural, no sentido dado por Leroi-Gourhan (1975), permeado por elementos mediadores (linguagem, técnica, instrumentos etc.). Na estrutura técnica das sociedades está coloca a questão da classificação/organização/exploração do mundo natural que culmina, mais recentemente, na idéia da mecanização do Planeta e da natureza artificializada, que permitem aos indivíduos refletirem sobre o trajeto de dissociação Homem/Natureza realizado pela sociedade onde estão incluídos, e principalmente, sobre a sua própria trajetória de adesão a determinados estilos de vida e de desenraizamento com relação a suas comunidades de origem e seus modos de vida.

É nesse sentido que a chamada “questão ambiental” pode ser colocada como uma preocupação urbana, pois o conceito de ambiente a que se refere, entendido enquanto ambiente técnico-cultural, nos termos propostos por Leroi-Gourhan (1975), é o ambiente que o trajeto antropológico da Civilização Urbano Industrial tornou possível. A cidade, enquanto obra humana, transforma a imagem do universo em um 
sistema simbólico em que a integração espacial do centro urbano com os confins do universo se dá a partir de um sistema rítmico de dias e distâncias. No atual plano técnico-econômico da Civilização Urbano-Industrial, os limites do espaço organizado em termos globais se tornaram atingíveis no tempo das operações cotidianas, fisicamente e, principalmente, simbolicamente nos quais as transformações ocorridas num canto do planeta podem ter efeitos globais, no espaço de um dia.

Colocada esta “questão ambiental” nesses termos, poderíamos perguntar, finalmente, qual o papel da água, ou dos debates internacionais como o Fórum Internacional das Águas em tudo isso? A questão dos usos dos recursos hídricos é fundamental para a passagem da noção de meio ambiente como paisagem, para a sua visão como ambiente que articula a dimensão do vivido ao território técnico-cultural da sociedade. Trata-se de uma mediação do conhecimento do ambiente enquanto microcosmos local para ser pensado em termos do Planeta, e principalmente, enquanto meio de uma diversidade de formas de vida social.

A questão da gestão dos recursos hídricos, da interdependência dos mananciais de água doce, interligados através das bacias hidrográficas está voltada para essa outra configuração espacial que se articula com as conexões simbólicas entre os diferentes cantos do planeta, na articulação dos diversos atores que desenvolvem atividades (econômicas, de lazer, administrativas) de uso da água, que são pensados a partir de um sistema em que todos os "usuários” da bacia hidrográfica em questão estão envolvidos. O menor gesto de degradação ambiental por parte de qualquer grupo social, ou mesmo indivíduo, passa a ser visto a partir da responsabilidade quanto às conseqüências ambientais para a chamada Biosfera, mas muito mais diretamente, para o seu grupo e para inúmeros outros grupos sociais - seus vizinhos, a cidade ao lado, o país adiante, a bacia hidrográfica, o continente.

Na medida em que órgãos internacionais apostam na construção de uma ética planetária de uso dos recursos naturais, é possível situar tais debates em três esferas, enquanto espaços sociais distintos e interdependentes, conforme Roberto Cardoso de Oliveira. A micro-esfera ética define-se por seu caráter particularista, ou seja, está voltada para as conseqüências das ações para determinado grupo social (a família, a vizinhança, o grupo religioso, o clube esportivo, o local de trabalho). A macro-esfera ética ocupa-se com os "interesses vitais comuns a toda a humanidade, envolvendo inclusive o destino dessa humanidade” (Oliveira, R.C. e Oliveira, L. R. C. 1996, p.21), ou seja, é onde tem lugar o debate do acesso à água como parte dos Direitos 
Humanos, normas morais que ganham dimensões universalistas. Finalmente, a mesoesfera é onde entra o Estado e a política nacional, articulada entre as diferentes regiões, que buscaria mediar os interesses particularistas com os interesses do Estado, e ambos com os direitos humanos universais. É também a esfera em que se constrói o trabalho do antropólogo, na medida em que os diálogos travados com os informantes e o diálogo interno com a bibliografia estão voltados para a produção etnográfica em imagem e na escrita, que possui igualmente contribuições e conseqüências éticas para os grupos e o conflito em questão.

\section{Meso-Esfera: O Delta na Bacia Hidrográfica do Guaíba}

Durante o Fórum Internacional das águas, um projeto de lei para o Delta do Jacuí causava polêmica. Regularizado em 2004, esse projeto transformou o Parque Estadual Delta do Jacuí em outra figura jurídica, uma Área de Preservação Ambiental, com o objetivo de dividir os 17,2 mil hectares do Delta em três áreas, uma reserva biológica de proteção integral e intocável (13,3 mil hectares), uma área de proteção ambiental em que atividades de agricultura e pesca seriam permitidas sob o controle do Estado (12,1 mil hectares), restando ainda 730 hectares de "área antrópica" onde a urbanização seria permitida, para comportar os mais de 15 mil habitantes das ilhas. O detalhamento dessas divisões dos territórios do Delta permanecem sendo debatidos. O que quero mostrar aqui é como essa discussão se inseria no contexto do fórum, e o quanto essa modificação pode ser interpretada como uma atualização da questão ambiental em torno da preservação das ilhas e áreas alagadiças do Delta à luz da política internacional de recursos hídricos.

Criado em 1976, o Parque Estadual Delta do Jacuí é ainda hoje motivo de grande polêmica na política ambiental do Estado. Localiza-se em plena Região Metropolitana de Porto Alegre, muito próximo à zona mais densamente edificada e urbanizada da capital. As atividades de implementação do Parque objetivavam promover o “disciplinamento de sua utilização”, destinando a utilização do espaço para o aspecto cultural e educativo (criando núcleos de informação, museus, centros de iniciação à natureza, viveiros de espécies) e prevendo o aproveitamento da natureza para atividades de lazer, recreação e esportes ligados ao meio e ao turismo. Pretendia-se ainda propiciar a pesquisa científica de um ecossistema em evolução através de estudos biológicos, geológicos, hidrológicos, humanos. (Parque Estadual Delta Do Jacuí - Plano Básico, 1979:20). 
Após mais de trinta anos de sua criação, o Parque passou pela administração de vários órgãos do Estado, obteve inúmeros financiamentos internacionais, teve algumas obras executadas, mas nunca foi implantado de fato. Os projetos de zoneamento das áreas do Delta do Jacuí seguiram enfrentando as dificuldades de implementação de uma unidade de preservação em plena Região Metropolitana da capital do Rio Grande do Sul. O que se apresenta, portanto, como "problema ambiental" desdobra-se em uma questão de habitação urbana e uso do espaço público, já que o processo de investimento em infra-estrutura de saneamento e transporte, de desalojamento e reassentamento, de indenização e regularização fundiária para mais de 15 mil habitantes, teriam de ser executados pelos governos municipais e estaduais em conjunto com as atividades de proteção ao ambiente.

Tais processos não são apenas um desafio do ponto de vista econômico para o Estado, mas igualmente uma intervenção na forma de organização espacial de tais populações nas ilhas, pois trata-se de uma população nada homogênea, reunindo das mais altas às mais baixas classes econômicas da região. As estratégias adotadas ao longo dos anos para tal foram muitas. As principais foram, sobretudo, o investimento em campanhas de conscientização dos moradores das ilhas, e também da cidade, através da promoção de políticas públicas, produção de documentários em vídeo, realização de eventos, cursos, palestras, distribuição de material educativo, em que a representação da paisagem do Delta do Jacuí é a grande tônica, mostrada a partir de sua fauna, sua flora, sua dinâmica das águas e banhados, suas belas luzes e cores.

É o recorte da bacia hidrográfica, segundo Paul Little ${ }^{17}$ (2006), que pode provocar uma reflexão diferenciada sobre a realidade socioambiental, por revelar conflitos latentes que não necessariamente se manifestam no espaço público formal, mas que permite identificar os recursos ambientais e atores sociais envolvidos, tanto localmente, quanto no que diz respeito a atores influentes à distância.

A valorização do Delta do Jacuí só pode ser compreendida pelo processo de valorização da Bacia Hidrográfica do Lago Guaíba, que por sua vez é formada pelas águas de nove sub-bacias hidrográficas. O Delta é justamente o espaço de ligação dessas águas, e tem sua importância principal, em termos ecossistêmicos, na

\footnotetext{
17 "Uma bacia hidrográfica é simultaneamente uma entidade geográfica que contêm distintos ecossistemas, uma área onde diversos grupos sociais, com suas respectivas instituições socioeconômicas, constroem um modo de vida particular e o locus para mobilização política e ambiental em torno do conflito socioambiental." Little, 2006, p.97.
} 
manutenção da qualidade das águas que são fundamentais para a continuidade da vida nesse ambiente, e dos ambientes da região.

Interpretando em termos da ética ambiental, a imagem do Delta do Jacuí traz a afirmação da responsabilidade do morador das ilhas para com os moradores de toda a região, e vice-versa. Algumas outras ações têm tentado disciplinar essa tomada de responsabilidade. Quanto ao processo de ocupação das margens por residências de alto padrão construtivo, foram iniciados processos para demolição de tais habitações no Ministério Público, bem como processos judiciais para pedidos de indenização do Estado. Já quanto às ocupações irregulares realizadas pelas classes populares, optouse por um processo de negociação política mais participativa, envolvendo lideranças locais, formando comissões, mas ainda assim permanecendo no plano dos debates jurídicos e burocráticos. As grandes questões quanto à execução desse processo permanecem. Como promover a urbanização dos terrenos alagadiços do Delta, com obras de saneamento, com colocação de energia elétrica e água encanada, sem comprometer o ambiente? Como transformar o morador irregular num cidadão pagador de impostos e serviços?

Durante os debates do Fórum Internacional das Águas, essa problemática da ocupação do Delta era deslocada da ocupação do solo para a questão dos usos das águas e sua importância. Tratava-se de uma problemática maior, que conseguia mobilizar divergências políticas em prol de uma mesma bandeira - a continuidade do "Programa Para o Desenvolvimento Racional, Recuperação e Gerenciamento Ambiental da Bacia Hidrográfica do Guaíba”, conhecido como "Pró-Guaíba”. Neste ano, estava em jogo a renovação do acordo entre os governos Federal e do Estado do Rio Grande do Sul com o Banco Interamericano de Desenvolvimento, comprometidos com a melhoria das condições ambientais da principal Região Hidrográfica do Rio Grande do Sul ${ }^{18}$.

Para entender a importância do Pró-Guaíba, é preciso compreender como as divisões em regiões hídricas, na política de recursos hídricos, passam a ser entendidas como unidades de planejamento sócio-econômico, constituindo-se em novas divisões políticas dos territórios. Apesar do Brasil ser considerado uma superpotência hídrica,

\footnotetext{
${ }^{18}$ As informações sobre o Pró-Guaíba que não constam em publicações científicas foram obtidas a partir de material disponibilizado pelo Estado, em especial a proposta para o Módulo II do programa (Pró-Guaíba, 1999), a publicação "Experiências em Educação Ambiental" (Rio Grande do Sul, 1998) e as informações que constam no endereço eletrônico http://www.proguaiba.rs.gov.br, último acesso em 13/10/2005.
} 
com 12\% das águas doces superficiais do mundo, $90 \%$ dessas águas estão concentradas nos Estados das regiões norte e centro-oeste, onde vivem apenas 15\% da população, enquanto as regiões nordeste, sudeste e sul possuem cerca de $10 \%$ do potencial hídrico superficial, detendo $85 \%$ da população nacional, e grande parte das atividades que consomem os chamados "recursos hídricos" na forma de abastecimento doméstico, força de geração de energia hidrelétrica (barragens), produção industrial, irrigação para a agricultura, reserva pesqueira, atividades de lazer. Todos esses consumos, ou usos diferenciados, geram o chamado "conflito de uso” dos recursos (Basso, 2004) da bacia.

Apesar da energia elétrica poder ser levada a diferentes regiões, os recursos hídricos em si são distribuídos na sua região hídrica. Dito de outra forma, as regiões economicamente mais importantes tem uma demanda cada vez maior de recursos hídricos, e uma preocupação crescente com a possibilidade de abastecimento da região hidrográfica em que estão inseridas. Assim como o Brasil, o Rio Grande do Sul é considerado privilegiado com relação à disponibilidade de águas superficiais, mas suas regiões mais densamente ocupadas enfrentam problemas com a qualidade de suas águas. O Rio Grande do Sul é formado por três grandes Bacias Hidrográficas ${ }^{19}$, sendo na Bacia do Lago Guaíba onde se concentram as maiores áreas urbanizadas do Estado, com mais de dois terços de sua população total e a maior parte igualmente das atividades industriais e econômicas que geram 70\% do PIB do Rio Grande do Sul.

O Lago Guaíba recebe, portanto, as águas (e também parte dos sedimentos, as cargas de efluentes e os dejetos) de seis grandes rios (que são divididos em sub-bacias hidrográficas) da Bacia Hidrográfica do Guaíba: Jacuí, Taquari, Antas, Vacacaí, Caí, Sinos e Gravataí. Ao longo do seu percurso, esses rios vão se juntando de modo que quatro deles (Jacuí, Caí, Sinos e Gravataí) desembocam num delta em forma de funil, o Delta do Jacuí, a noroeste de Porto Alegre, formando o Lago Guaíba que banha a cidade (Rio Grande do Sul, 1998). É nessa dinâmica que desponta a importância do

\footnotetext{
${ }^{19}$ Uma bacia hidrográfica é formada pela drenagem de outros cursos de água, formando um rio ou $\operatorname{lago}^{19}$. A bacia é, portanto um sistema de canais de escoamento inter-relacionados que contribuem para o abastecimento dos chamados "lençóis freáticos", águas subterrâneas que são a garantia da perenidade desses cursos de água, além de serem fundamentais para manutenção da qualidade de suas águas. Os principais impactos que ameaçam as bacias hidrográficas são a contaminação e a impermeabizilização desses lençóis freáticos. A contaminação ocorre por efluentes vindos da indústria (dejetos), da agricultura (agrotóxicos) e do meio urbano (esgoto e lixo). A impermeabilização do solo impede o abastecimento do lençol freático pela absorção das águas superficiais causando seu esgotamento. A impermeabilização é provocada pela erosão e o transporte de sedimentos (areia, madeira, etc) vindos principalmente da região agrícola, e pela introdução de superfícies impermeáveis, próprias do processo de urbanização como o asfalto e os aterros (Pires, 2000:209 e Basso 2004).
} 
Delta do Jacuí, já que seus banhados e terrenos alagadiços, em uma área de 17,2 mil hectares no centro desse encontro de águas seriam justamente uma "esponja” natural que não apenas filtra os sedimentos, mas também absorve boa parte dessas águas, contribuindo para o abastecimento do lençol freático e a regulagem das cheias em toda a região. Sob tal ponto de vista, o Delta do Jacuí é muito mais do que um "santuário ecológico” de espécies animais e vegetais, é como que o coração de toda essa região hidrográfica, que sofre o impacto diário de mais de 3.700 toneladas de lixo domiciliar, 16.500 litros de agrotóxicos, $890 \mathrm{~m}^{3}$ de resíduos de indústrias e 960 mil $\mathrm{m}^{3}$ de esgoto ${ }^{20}$.

O Delta encontra-se, sob este ponto de vista, em relação de interdependência ecossistêmica e econômica em relação a toda a Região Hidrográfica do Guaíba, que abrange territórios bem diversificados, sendo no total 84.763,54 Km², mais de 250 municípios (30\% do território gaúcho), onde vivem mais de seis milhões de habitantes, a maioria vivendo em cidades (83,5\%). Essa interdependência entre tantas pessoas e instituições (prefeituras, secretarias do Estado e dos municípios, empresas, associações civis, etc) tornou-se um desafio de gestão para o Estado, na medida em que não bastariam soluções tecnológicas para o problema (filtros, estações de tratamento e monitoramento, mudanças na legislação), sendo necessárias ações com governos e população. Para tal foi criado o Pró-Guaíba, financiado pelo Banco Interamericano de Desenvolvimento (BID), tendo investimentos até 2002 de cerca de US\$ 220,5 milhões. Concebido em 1989, e iniciado em 1995, o valor total do PróGuaíba é estimado em 1,2 bilhões de reais ${ }^{21}$. Seu objetivo principal é melhorar o ambiente da bacia $^{22}$ através da ação do Estado, sendo executado por vários órgãos municipais e estaduais, com a expectativa de reverter o quadro de poluição das águas favorecendo o desenvolvimento sustentável (Basso, 2004). Envolveu a implementação do sistema de coleta e tratamento de esgotos em Cachoeirinha, Gravataí e Porto Alegre, a conservação de parques e reservas naturais (Delta do Jacuí e Itapuã), o monitoramento da qualidade da água, do solo e do ar, o controle e o manejo de agrotóxicos, reflorestamento, construção de estações de tratamento de resíduos sólidos, além de campanhas de educação ambiental, elaboração de planos

\footnotetext{
${ }^{20}$ Dados oficiais do Programa Pró-Guaíba: http://www.proguaiba.rs.gov.br/prog_desafio.htm

${ }^{21} \mathrm{http}: / /$ www.proguaiba.rs.gov.br

${ }^{22}$ O Pró-Guaíba “...tem o objetivo geral de criar as condições necessárias para a utilização racional dos recursos naturais, recuperação da qualidade ambiental nas áreas urbanas e rurais, bem como executar o manejo ambiental sustentado nas atividades agrícola, pecuária, florestal e industrial.” Rio Grande do Sul,1998:07.
} 
diretores de bacias hidrográficas, cadastramento de indústrias poluidoras, treinamento de técnicos e o sistema de informações geográficas da bacia (Basso, 2004).

Indiretamente, no entanto, poderíamos dizer que o volume dos investimentos contribuiu também para uma maior circulação de conceitos como ecossistema, bacia hidrográfica, flora e fauna, que através de campanhas publicitárias e ações de educação ambiental, que passaram a orientar uma mudança na abordagem do Poder Público local com relação às questões que envolvem o meio ambiente. Antes consideradas problemas do campo da Saúde ou da Economia (agricultura, geração de energia), tais questões ambientais foram direcionadas a novas instituições a partir da década de 1990. No mesmo período em que se concebeu e se deu início ao PróGuaíba foram criadas a Secretaria Estadual de Meio Ambiente (SEMA), os Departamentos de Florestas e Áreas de Proteção (DEFAP) e de Recursos Hídricos (DRH), fundações como a Fundação Estadual de Proteção Ambiental (FEPAM) e a Fundação Zôo-Botânica do RS, além de novas formas de organização entre Estado e sociedade como os comitês de gerenciamento de bacia hidrográfica, o Conselho de Recursos Hídricos (CRH) e o Conselho Estadual de Meio Ambiente (CONSEMA), nos quais atuam junto ao poder público inúmeras formas de organização da sociedade civil. Todos os técnicos e profissionais atuantes nessas instituições são colocados em situação de diálogo com as demais instâncias do poder público, com empresas e cidadãos de todo o Estado, chamados ao debate em nome dessa nova forma de se pensar as territorialidades pela sua interdependência em função da água.

O Brasil, e em especial o Rio Grande do Sul, vem adotando o modelo de gestão participativa de recursos hídricos baseado no sistema de comitês de gerenciamento de bacia hidrográfica, tomando a Bacia Hidrográfica como unidade de planejamento. Os comitês reúnem representantes dos chamados usuários da água, sendo estes indústria e agroindústria, associações de moradores, colônias de pescadores, ONG’s, instituições técnicas e órgãos públicos (de abastecimento de água e de saneamento) dos municípios de cada região hidrográfica que irão debater as regras de uso da água (incluindo o custo financeiro para cada atividade econômica e a destinação das arrecadações) em setores da bacia, a serem definidos com base em estudos técnicos.

Sendo considerada como um bem universal, e seu acesso um direito humano fundamental, a água na legislação brasileira, ou os "recursos hídricos”, entendidos como recursos econômicos, são considerados de domínio público, como um "bem 
difuso” do qual o Estado não é proprietário, mas seu gestor, com a responsabilidade de regular os usos privados das águas e seus conflitos entre interesses diversos (Soares, 2003). Trata-se de um modelo de planejamento e gestão, ou administração pública, que possui o aval internacional, mas que, no entanto, encontra resistências e dificuldades de implementação localmente.

Os Comitês encaminham o chamado "enquadramento da bacia”, decidindo por quais usos serão permitidos em uma divisão igualmente arbitrária da região hidrográfica, e a partir daí decidem igualmente políticas de recuperação de ecossistemas, e de indenização de impactos como os custos dos usos diversos dos recursos hídricos por diferentes atores. É por isso que os conflitos em meio a essa “comunidade de comunicação” (Oliveira, R. C. E Oliveira, L. R. C., 1996), vêm se dando no embate entre profissionais da área técnico-científica (biólogos, arquitetos, engenheiros, hidrólogos) com representantes de setores como os grandes produtores de arroz, que necessitam de grandes quantidades de água para irrigação das lavouras, assim como as empresas que atuam na área de geração de energia hidroelétrica, que realizam empreendimentos de grande impacto ambiental.

O modelo de gestão, pautado pelo conflito de interesses de uma grande diversidade de “usuários da água” como gerador da política participativa em torno do interesse comum pela preservação da qualidade das águas, encontra entraves na mobilização de outros setores que poderiam reivindicar investimentos em saneamento básico, recuperação de cursos de água e mata nativa, e que, no entanto, não atingem a representatividade esperada pelo modelo. São justamente os setores mais afetados financeiramente os que mais têm se atualizado em termos do funcionamento jurídico dessa política da água, e que têm por isso mesmo cada vez mais disputado os cargos de direção dos comitês com seus tradicionais ocupantes, os técnicos do Estado que atuam no sistema de recursos hídricos.

Tendo assistido a algumas reuniões de comitês de bacia como o Comitê Lago Guaíba, o Comitê Sinos e o Comitê Tramandaí, e tendo dialogado com alguns dos técnicos atuantes nos comitês, tomei conhecimento de suas dificuldades em conseguir maior mobilização da sociedade civil e dos próprios agentes do Estado (vereadores, deputados, prefeitos) para conquistar força política por parte dos comitês, e, logo, maiores verbas para implementação de seus encaminhamentos. Por um lado, os técnicos apontam a necessidade de um maior conhecimento dessa visão sistêmica por parte da sociedade em geral, chamada de "informação" ou "conhecimento técnico", 
quanto à dimensão regional que os impactos locais possuem no ambiente (poluir um riacho é comprometer toda a bacia), para que se possa atuar no debate ético em prol da bacia hidrográfica como um todo. Por outro lado, outra grande dificuldade dos comitês, dos quais participam ONG’s ambientalistas, associações comunitárias (como as colônias de pescadores ou sindicatos rurais) é a de encaminhar as discussões do grupo para questões de ordem executiva quanto à burocracia do Estado, através do conhecimento operacional das leis que articulam essas inter-relações entre os poderes municipal, estadual e federal.

Esse era um dos motivos da realização de eventos como o Fórum Internacional das Águas. Por um lado, informar outros setores governamentais e empresariais sobre a legislação que institui a política de recursos hídricos e o seu sistema de gerenciamento, para conquistar novos aliados tanto no poder executivo quanto nos quadros de funcionários de instituições governamentais e de empresas. Por outro lado, mobilizar a sociedade civil não só para a promoção de uma ética ambiental quanto às suas práticas cotidianas, mas para que mais entidades queiram se sentir representadas, sendo levadas a ocupar de forma efetiva espaços políticos nos comitês.

\section{Navegando nas águas da Mãe Oxum}

Em setembro de 2003, pude acompanhar as negociações de funcionários e técnicos relacionados à Secretaria Estadual do Meio Ambiente (RS) com representantes de entidades religiosas de Porto Alegre, para realização da Romaria das Águas 2003. A Romaria das Águas é um evento que já havia tido outras edições, em que o Programa Pró-Guaíba do Governo do Estado do RS havia apoiado agentes religiosos atuantes nas ilhas de Porto Alegre, sobretudo a congregação católica Irmãos Maristas, para transformarem a procissão de Nossa Senhora Aparecida, padroeira da comunidade da Ilha Grande dos Marinheiros, em uma procissão fluvial, levando a imagem do santuário que se encontra nas ilhas para a margem oposta, em Porto Alegre.

Curiosamente, portanto, inverte-se essa relação entre a comunidade de papeleiros das Ilhas, considerada de ocupação irregular no Delta do Jacuí, pois a Romaria das Águas coloca justamente um ritual de fundação dessa comunidade como evento de educação ambiental. A romaria unia projetos diversos. Fazia parte de projetos de assistência social, por parte de algumas congregações da Igreja Católica. 
Era também uma forma de divulgação e educação ambiental ${ }^{23}$ para o governo estadual. Para muitos fiéis e devotos das santas e dos orixás das águas, significava uma retomada da procissão fluvial tradicional (e por muitos anos interditada) da cidade, realizada todo 02 de fevereiro na festa de Nossa Senhora dos Navegantes (ou de Iemanjá para os adeptos de religiões afro-brasileiras), em que os barcos de pescadores e outras embarcações são benzidas e protegidas, e oferendas de agradecimentos são lançadas às águas.

Era também uma manifestação política do Clube de Mães Unidos da Ilha Grande dos Marinheiros, e do pessoal do galpão de reciclagem da ilha. Eram projetos a princípio convergentes, na medida em que a verba internacional do Programa PróGuaíba, financiado pelo Banco Interamericano de Desenvolvimento para a realização de inúmeras atividades relacionadas à despoluição das águas do lago, circulava na forma de infra-estrutura do evento e assistência aos participantes (doações de alimentos, de roupas, de combustível para as embarcações), mobilizados pela fé na força da santa em justamente trazer dádivas das águas. Iniciada em 1994, a procissão foi adotada como parte de ações de educação ambiental do Governo do Estado para as novas bacias que compõe a região hidrográfica do Lago Guaíba. Em 2003, foi ampliada para todo o estado do Rio Grande do Sul.

Essa foi pelo menos a estória que me foi relatada, pelos organizadores da edição do evento em 2003. A medida em que fui ouvindo pontos de vista diversos sobre a mãe das águas de Porto Alegre, pude compreender melhor os pontos de amarração e os nós conflitantes entre os interessados na festa das águas. Ocupei o lugar de um observador participante, na medida em que produzi, na companhia de colegas do núcleo de pesquisa da Universidade, imagens em vídeo da procissão fluvial e das cerimônias realizadas, e ainda entrevistei algumas lideranças da participação das comunidades das ilhas sobre a importância da procissão e do evento. As imagens foram exibidas em alguns eventos posteriores da política de recursos hídricos (congressos e fóruns), e disponibilizadas também em website.

Em setembro de 2003, assisti a uma reunião entre técnicos e funcionários ligados ao Programa Pró-Guaíba, da Secretaria Estadual de Meio Ambiente do Rio Grande do Sul, e representantes de diversas entidades religiosas atuantes no estado.

\footnotetext{
${ }^{23}$ Uso o termo "educação ambiental" como expressão êmica, visto que nenhuma atividade educativa em realidade tenha sido de fato realizada durante esses eventos, apenas eventos, campanhas de mobilização social e outras ações publicitárias que, no entanto, foram cunhadas com o termo "educação ambiental”.
} 
No ano internacional da água doce, o governo estadual dava continuidade à transformação do evento, da sua dimensão local, para uma investida em todo o estado, em meio às atividades internacionais da Semana da Água.

Como preparação para a Romaria das Águas, uma “festa popular, de caráter espiritual, ecológico e social” ${ }^{24}$ foram realizadas atividades de educação ambiental nas nove bacias da Região Hidrográfica do Lago Guaíba. Cada um dos comitês de bacia reuniu pessoas de sua comunidade (alunos de escolas e universidades, membros de ONG's, associações e clubes recreativos) para realizarem uma viagem até uma das nascentes dos rios que formam a bacia hidrográfica, onde coletaram uma amostra das águas das nascentes. Essa água estava destinada a uma cerimônia de mistura das águas de todas as nascentes no Lago Guaíba no dia 12 de outubro.

O objetivo, por parte dos órgãos governamentais, era claramente o de inserir a procissão em uma programação maior de ações de “conscientização sócio-ecológica” da Semana da Água destinadas à população em geral. As atividades incluíam a participação de todas as organizações religiosas, espiritualistas, ou mesmo étnicas que estivessem dispostas a manifestarem-se no chamado "Ato Macroecumênico" de destinação de energias positivas para as águas do Lago Guaíba. No entanto, essa reunião de tantos credos pode ser lida por outro olhar menos preocupado com a harmonia e o universalismo católicos, pois esta não deixava de ser a instituição religiosa dominante nas articulações que antecederam o evento. A Romaria das Águas foi para algumas dessas instituições religiosas uma mera formalidade e uma oportunidade de divulgação. Para outras, foi uma espécie de combate.

A simples presença dos representantes religiosos na reunião da programação da Romaria já dava margem à interpretação do que estava guardado para o dia 12 de outubro. Estavam representados na reunião a Organização Brahma Kumaris e a Igreja de Jesus Cristo dos Últimos Dias, que assim como as etnias indígenas Kaingang e Guarani, o movimento Hare Krishna, a religião Islâmica, que não compareceram à reunião mas haviam confirmado presença no evento, manifestaram apenas a disposição de colaborar com o protocolo. Mas a presença maciça na reunião era de mais de 15 representantes de casas de religião afro-brasileiras, entre umbandistas, casas de nação e linha-cruzada, batuqueiros, assim como representantes de federações diversas. Reivindicavam um espaço de tempo maior no evento, visto que a

\footnotetext{
${ }^{24}$ Como descrita em panfleto de divulgação do evento.
} 
programação lhes demandava escolher um único representante para ter direito a alguns minutos de manifestação. Filhas de Oxum e Iemanjá (divindades das águas), pediam para si a responsabilidade de representar as casas de religião. Outras hierarquias se apresentavam, entre as tendências e famílias de santo locais. A reunião que era apenas para “comunicar” a programação, acabou virando uma assembléia e uma medição de forças. Lamentavam a ausência de representantes da Igreja Católica na reunião, pois estes haviam se reunido no dia anterior com os organizadores do evento e definido sua parte na programação.

Em meio ao combate que se travava na reunião, uma voz se sobressaía, a de Mãe Bia, do Centro Reino de Iemanjá e Oxóssi da Ilha da Pintada, pois estava somava a seu favor o pertencimento aos territórios onde se originara a procissão, e o fato de participar como liderança local nas reuniões técnicas entre moradores do Delta e órgãos administrativos do Parque. Reivindicava a participação dos idealizadores da Romaria, representantes do santuário da Ilha Grande dos Marinheiros, de onde a imagem seria trazida, nas cerimônias a serem realizadas na margem oposta. Era uma proposta que seguia na contramão da programação proposta pelo Estado, que justamente tentava distanciar o sentido da festa da celebração de divindades locais, com o objetivo universalista de contemplar todos os "Habitantes do Rio", conforme o próprio nome do projeto colocava, incluindo toda a Região Metropolitana de Porto Alegre e as cidades relacionadas às nove bacias da Região Hidrográfica.

Esse acabou sendo o percurso da Romaria, dividida em três momentos, da sua dimensão mais local a mais regional. O primeiro momento, realizado no santuário da Ilha Grande, com a população local, reuniu os moradores do Arquipélago no barco que trouxe a santa até o Clube Náutico do Estado, à beira do Lago Guaíba, no Bairro Navegantes. No clube Náutico, reuniram-se as pessoas que iam participar da procissão fluvial: pescadores, barqueiros e donos de lanchas que foram benzidas por um padre católico, fiéis de religiões afro-brasileiras, que participaram das manifestações de umbandistas e batuqueiros em homenagem à Mãe das Águas doces (Oxum) e finalmente as delegações dos comitês de bacia do interior do estado que foram trazidos para participarem da procissão fluvial. A população seguiu a bordo dos barcos de passeio da Ilha da Pintada, que costumam fazer trajetos diários no lago, que foram acompanhados ainda de barcos de pescadores, jetskis, lanchas, embarcações da Marinha do Brasil, todas seguindo o barco principal, que conduzia a imagem da santa e as muitas autoridades governamentais e religiosas presentes ao evento. 
Passando pelos canais do Arquipélago de Porto Alegre, a procissão chegou à praia do Gasômetro, onde foi realizado o “Ato Macroecumênico”, no qual cada autoridade religiosa dedicou um canto ou uma oração às águas. Finalmente realizouse um “ritual de mistura das águas”, reunindo as águas das nascentes das nove bacias hidrográficas, que foram lançadas então de volta ao Lago Guaíba, simbolizando a união e a interdependência das bacias e de suas populações, pela qualidade das águas enquanto fonte de vida da coletividade.

Com as pessoas que participaram das atividades de educação ambiental, como a coleta das águas das nascentes, o evento conseguiu provocar certo estranhamento quanto a essas inter-relações entre o seu ambiente de origem e as águas do Guaíba. Com o olhar em deslocamento a bordo dos barcos de passeio durante a Romaria, revelava-se a surpresa de algumas pessoas com o ambiente das ilhas e canais de navegação, constatando o fato de que a água que “desce” dos rios que passam por suas cidades vai formar finalmente o corpo hídrico do lago.

Mas apesar da sua orientação democrática e universalista, o evento não teve o sucesso esperado junto à população de Porto Alegre, tendo um público reduzido, composto basicamente por pessoas que se organizaram junto aos comitês de bacia do interior do estado para participar da festa, pelos membros das casas de religião afrobrasileiras, e pelos representantes políticos das comunidades das ilhas.

Já em termos de religiosidade, o evento parecia menos católico e menos ecumênico, e muito mais um culto afro-brasileiro, com o som dos tambores, dos cantos e o colorido das roupas tomando conta da cena. O que teria atraído esses segmentos da população da cidade para as atrações da Semana Interamericana da Água? Certamente não foi o evento em si que conseguiu mobilizar tantos devotos da mãe das águas doces, mas, pelo contrário, foi provavelmente a própria Mãe das Águas que teve esse poder. O fato das atenções da cidade estarem voltadas para a água coincidiu com um momento importante politicamente para umbandistas e batuqueiros, que reivindicavam seus direitos a estarem próximos das mães das águas e fazerem oferendas.

Do ponto de vista da meso-esfera ética, pode-se pensar o quanto a abordagem da política dos recursos hídricos, pautada pela negociação dos conflitos de uso das águas, revelou conflitos de uso religioso de espaços como as margens da cidade. Trata-se de um momento em que as diferentes federações afro-religiosas vêm se articulando com o poder público, promovendo campanhas de conscientização para o 
uso de material orgânico nas oferendas a serem lançadas nas águas, assim como embates quanto à sacralização ${ }^{25}$ de animais vinham sendo travados contra deputados e vereadores evangélicos, ou adeptos a movimentos ecológicos.

Em fevereiro de 2004, encontrei o mesmo grupo que realizou a procissão fluvial da Romaria retomando a procissão por água na festa de Iemanjá (Nossa Senhora dos Navegantes), repetindo o mesmo ato ecumênico no clube náutico em fevereiro, porém com menos público. Para o clube náutico iam não apenas os fiéis que fizeram a procissão de barco e que participavam da festa ecumênica, mas igualmente os devotos que fizeram a procissão a pé, e que queriam realizar oferendas a Iemanjá como forma de agradecimento por dádivas concedidas, lançando flores, velas, perfume e pequenas embarcações nas águas que eram vendidas às centenas nas bancas de comércio montadas próximo a igreja de Navegantes. Os espaços do Cais do Porto Navegantes, mais próximos à igreja de mesmo nome, que tinham contato com o lago, estavam naquele ano fechados, levando os devotos de Iemanjá para longe do espaço de celebração católica ${ }^{26}$.

Sem entrar no momento na polêmica de cunho étnico-religioso que se instaura nas interdições ao culto de Iemanjá a beiras das águas, é possível perceber que as discretas oferendas, que eram interditas, ou mal vistas no dia 02 de fevereiro, ocupavam o centro das atenções, os microfones e as lentes da Romaria das Águas, numa celebração a Oxum por ocasião da festa de Nossa Senhora Aparecida. A realização da Romaria era mais uma oportunidade para umbandistas e batuqueiros trazerem para a frente da cena pública o uso religioso de espaços que lhe são tradicionalmente sagrados na cidade, como a Praia do Gasômetro.

A imagem de Nossa Senhora Aparecida, padroeira dos pescadores, uma imagem negra de Maria, surgia como símbolo importante da política ambiental de tamanha abrangência. Mas neste caso, com algumas particularidades. Como um mito de fundação de uma comunidade de catadores de material reciclável acaba por tematizar uma política ambiental de tamanha abrangência?

\section{Micro-esfera - os papeleiros, as carroças e a água}

\footnotetext{
${ }^{25}$ O termo sacralização é usado pelos batuqueiros e umbandistas, com o sentido ritual e simbólico que se opõe às representações de "matança" e "sacrifício" de animais do qual são acusados.

${ }^{26}$ A procissão da senhora dos Navegantes passou a ser feita exclusivamente por terra a partir da década de 1980, apresentando uma imagem singular de remadores conduzindo por terra a imagem da santa, que contrasta com a festa embarcada de outras cidades portuárias do Brasil. (Cavedon, 1992)
} 
Em sua casa, à beira do Lago Guaíba, na Ilha Grande dos Marinheiros, Nazaret, então com 60 anos de idade, me mostrava em fotografias antigas o mato no fundo das fotos, comentando o crescimento da comunidade e da ocupação da ilha. Lamentava a perda do mato, mas se solidarizava com as famílias que chegavam à ilha. Enquanto que muitas pessoas do lado sul da ilha vinham da Ilha do Pavão, o lado norte viera então da região onde foi construída a auto-estrada Freeway (BR 290). Outros ex-moradores da Ilha do Pavão foram para a Restinga em 1970 (Zona Sul de Porto Alegre) e retornaram por volta de 1990. Durante sua narrativa, Nazaret reflete sobre sua trajetória, trabalhando com lixo reciclável, mas também como empregada doméstica no Bairro Navegantes, em serviços gerais na escola na ilha, e atualmente assumindo as atividades do clube de mães e fazendo atendimento como praticante da religião umbandista.

O sentido para o qual apontava o relato de sua trajetória lembrava outras narrativas autobiográficas que tive oportunidade de ouvir de moradores das ilhas, em que são marcados gestos de destruição e re-fundação de formas de vida coletiva entre os territórios da região. Trata-se de grupos e não indivíduos que configuram esse nomadismo que narra uma outra história do crescimento da Região Metropolitana do Estado do Rio Grande do Sul, da construção de grandes estradas, da passagem de uma ambiência rural para uma ambiência urbana (no sentido da aglomeração) nas ilhas à entrada da cidade, na transformação da zona do Cais do Porto e dos caminhos de entrada e saída do centro urbano.

Ao narrar a lenda da santa dos papeleiros, conta como surgiu o trabalho com lixo nas ilhas do Pavão e dos Marinheiros, considerado hoje pelo Estado como grave problema ambiental no Delta do Jacuí:

\section{Nazaret (Ilha Grande dos Marinheiros, 2003)}

A estória do papelão mesmo que começou aqui foi quando a prefeitura fez o Pavão de lixão. Que ali eu também aprendi, entendeu? Quando a Ilha do Pavão, a prefeitura largou o lixo ali, as crianças iam pra ali colher lixo. A gente dizia lixo. Ia colher ali para vender. Ferro. Plástico. Lata. A criançada começou a colher. Aí, eu comecei a trabalhar na minha casa. Aí vinham os caminhão das loja trazer porque as loja não catavam papelão, hoje eles estão recolhendo. Então tirava, ganhava lixo da JH Santos, da Telefônica, aqueles restos de material velho e eu catava papelão em casa. Aí, Como tinha essas mães e eu cuidava das crianças para as mães trabalharem e era difícil pegar serviço. O Irmão Antônio Cechin chegou pra mim, trouxe uma comissão de pessoas pra olhar o trabalho. Eu tinha todas aquelas caixas separadas. Aí o irmão Antônio disse - Nazaret o que tu acha de nós fundarmos um galpão? Este galpão vai ser fundado para mulheres trabalhar... Aí ele fundou o galpão de reciclagem... As pessoas 
atravessavam a ponte e buscavam papelão e colocavam ali para os outros trabalharem. Aí depois ele começou a comprar dos carroceiros, né? Começou a comprar dos carroceiros. Aí foi, foi, foi não dava vencimento. Aí começou a comprar da comunidade, né? E as mulheres trabalhando... Aí parece que ele ficou doente, não me lembro bem da estória, aí foi quando ele passou para a prefeitura. E os caminhão não entraram mais na ilha, das lojas, pra trazer, porque o ICM não deixa porque era lixo. ICM é aquela fiscalização que tem ali no Pavão. Aí eles começaram a trancar os caminhões. ... Então ali que surgiu o galpão de papeleiros, das mulheres papeleiras. Agora parece que tem duas associações ali dentro. E aí a prefeitura começou a trazer com os caminhões o lixo, pras pessoas trabalharem. Que tá fraco, né? Não tem serviço para as pessoas ali. E assim foi a nossa luta."

Desvela-se aqui um encontro da trajetória de Nazaret e dos moradores das ilhas com a própria trajetória da política ambiental em Porto Alegre. O lixão colocado pela prefeitura de Porto Alegre na Ilha do Pavão, entre 1973 e 1976, foi um dos componentes da ocupação irregular do Delta, na medida em que ofereceu uma alternativa de renda em um ponto estratégico da cidade, a pouca distância do centro da cidade e principalmente do Bairro Navegantes e da Avenida Voluntários da Pátria, onde situavam-se as firmas a que Nazaret se refere, em territórios ocupados por trabalhadores que atuaram nas obras de aterramento de toda a região. Já a formação do galpão de reciclagem da ilha, inicialmente política de assistência social da Congregação Marista, oficializado pela Prefeitura de Porto Alegre em 1990 e financiado pelo próprio Programa Pró-Guaíba como atividade modelo, concorre com um mercado de trabalho informal, de galpões particulares, catadores autônomos e famílias que separam no pátio de casa o lixo trazido de outros bairros da cidade. Toda sexta-feira, os caminhões dos atravessadores compram o material separado pelo pessoal das ilhas e levam para revender. O lixo que não é vendido, em alguns casos, acaba tendo outros usos no solo da ilha, sendo o principal a função de aterro dos terrenos alagadiços, causando problemas de saneamento e saúde para a população.

A atual unidade de reciclagem de lixo "Associação dos Catadores de Materiais de Porto Alegre”, origina-se do “Grupo de Apoio às Mulheres Papeleiras”, a primeira unidade de triagem de resíduos sólidos, fundada em 1986, tendo papel importante na divulgação dessa política municipal de coleta seletiva e de geração de emprego e renda. Trabalho desenvolvido pelas Comunidades Eclesiais de Base, o galpão surgiu a partir de um movimento social para organizar os papeleiros, trabalhadores do lixo, em cooperativas. O depoimento de Antônio Cechin em 1995 (o padre Cechin que também aparece no depoimento de Nazaret), é revelador de como uma questão de saneamento 
municipal foi transformada em política de assistência social, no caso da Ilha dos Marinheiros:

\begin{abstract}
Antônio Cechin (Ilha Grande dos Marinheiros, 2003)
"Deus não quer que a gente jogue coisa no lixo. Porque a Nossa Senhora Aparecida foi uma estátua quebrada, jogada no lixo. Então o povo não admite, esse negócio de jogar no lixo uma santa, pro povo é um crime. Então o pessoal se juntou, pediram cola, colaram a imagem, né? Encostaram numa coluna, já fizeram uma oração, né? E aí então a gente contou a história de Nossa Senhora Aparecida, que é semelhante porque em São Paulo, é a Padroeira do Brasil, hoje. Foi uma pescaria, trabalharam a noite inteira não pescaram nada, e quando foi de manhã, indo embora, já no arrastão da rede, vem o corpo de uma imagem sem cabeça. Estranharam, segundo arrastão veio a cabeça que faltava. Então ela foi catada na rede dos pescadores e depois reciclada. E diz que depois lançaram a rede de novo, encheu a rede de peixe. E pra gente pobre é milagre, né? Aí começou a devoção a Nossa Senhora Aparecida das Águas, e aqui a gente fez a mesma coisa com os catadores, né?”
\end{abstract}

Atualmente, já não se trata de um galpão de mulheres recicladoras. O grupo, hoje, constitui-se em uma associação de pequenos grupos familiares, cada um vivendo do que vende. A única fonte de lixo do galpão é o caminhão de coleta seletiva municipal, os outros galpões compram o lixo das demais pessoas que trazem por conta o que catam nas ruas. Chegam os caminhões da coleta seletiva, o pessoal do galpão separa, e eles mesmos vendem para empresas que compram, cada uma, um material - papel, diferentes tipos de plástico, vidro.

As distinções que Cristina Sosniski (2006) estabeleceu, ao realizar um estudo etnográfico entre os trabalhadores do lixo na Ilha Grande dos Marinheiros são bem úteis para esclarecer as diversas facetas dessa atividade. Os trabalhadores do galpão, ou unidade de triagem na linguagem técnica, são os chamados recicladores, treinados por agentes da política pública local, que além de trabalharem em uma atividade oficialmente reconhecida, participam de cursos, palestras, voltados para questões de saúde e segurança e organização do processo produtivo na forma associativa, ou de auto-gestão. (Sosniski, 2006, p.13).

O princípio comunitário do galpão não é apreciado por muitas famílias que preferem depender só de si mesmas para conseguir o sustento mensal. São os chamados "carroceiros" e "catadores", que desempenham enquanto atividade familiar o trabalho com o lixo (Sosniski, 2006, p.13), sem participar das mesmas políticas públicas que os recicladores, atuando em um mercado informal do lixo na cidade. 
Mas do ponto de vista da atividade, e em relação às demais redes sociais do Arquipélago, as três categorias são percebidas nas ilhas pela forma estigmatizada do papeleiro que aparece na narrativa de Nazaret, ou do reciclador como uma forma positivada da atividade enquanto inserida no mercado de trabalho urbano. Mas são categorias que se mesclam, pois muitas famílias empregam outros moradores das ilhas nas atividades com o lixo, enquanto outros já tiveram em sua trajetória profissional tanto a atividade como reciclador do Galpão que atua em parceria com a prefeitura, quanto participaram ou participam das atividades nos galpões particulares e quintais, ou mesmo com carroças e carrinhos nas ruas da cidade.

Poderíamos enumerar muitas razões práticas e simbólicas para tantas pessoas aderirem ao trabalho com lixo reciclável nas ilhas, como a maior renda em comparação ao salário mínimo para trabalhadores não qualificados no mercado de trabalho, a condição de “não depender de ninguém”, que conforma o que Fonseca (2000) aponta como um componente importante das atividades das classes populares urbanas que já estão distantes demais do mercado regular de trabalho. Soma-se ainda o princípio da unidade familiar como força de trabalho e o uso do espaço doméstico para o trabalho, a relação da atividade no lixo com saberes ligados à criação de animais e o uso do cavalo como transporte urbano, sendo que nas ilhas é tradicional a atividade de capineiro, a extração e o transporte do capim nos caícos ou nas carroças, que antigamente abasteciam as muitas carroças que circulavam pela capital ${ }^{27}$.

Mas o que se revela, sobretudo, é que a informalidade do mercado do lixo urbano reciclável, mantendo uma mão-de-obra de baixo custo com a adesão dos moradores das ilhas do Pavão, Marinheiros, e Flores ao trabalho com lixo, e a setorização dessa atividade em um mesmo local, oferece vantagens aos atravessadores que compram o material reciclado, como a possibilidade de fazer a coleta de uma vez só, um dia por semana, liberando de restrições legais as empresas que não arcam com os custos da separação do material. Cada vez maiores, alguns galpões particulares foram construídos na Ilha dos Marinheiros, aproveitando essa referência comercial da vila dos papeleiros, em um local que se encontra na saída da cidade, na proximidade de sua zona industrial. A trajetória do lixo nas ilhas é só uma parte de um processo

\footnotetext{
${ }^{27}$ São saberes e fazeres que unem antigos moradores, que viveram a infância no tempo em que se criava gado leiteiro nas ilhas, e novos moradores, muitos vindos do interior do estado, que igualmente filiam-se à tradições rurais do Rio Grande do Sul em que o transporte a cavalo tem valor simbólico importante. Aprender a montar e a conduzir as carroças são uns dos primeiros aprendizados das crianças que têm essa possibilidade.
} 
maior de ocupação das regiões baixas, alagadiças, e até então desvalorizadas no ambiente urbano.

A narrativa de Nazaret acrescenta um fator importante para o mito de origem, as razões simbólicas para a comunidade de papeleiros mobilizar-se pela devoção a essa senhora das águas. Ao narrar o começo da devoção à imagem da Nossa Senhora das Águas, Nazaret narrou a sua própria trajetória em meio à trajetória dessa comunidade norte com a qual se identifica na ilha. A devoção à santa remonta a fundação do viver coletivo dessa comunidade em meio à natureza do Delta do Jacuí e a sua recriação enquanto espaço vivido, acrescentando outros contornos aos laços de pertencimento dessa comunidade ao solo alagadiço das ilhas.

\section{Nazaret (Ilha Grande dos Marinheiros, 2003)}

"Moro há quarenta anos dentro da ilha e desde 1977, 1976 a gente vem acompanhando, né? Nós morávamos no Pavão. A prefeitura veio e desmanchou a minha casa. Demoliu com a minha casa. E eu fui pra rua com os meus filhos. Debaixo da Nossa Senhora da Conceição eu me agasalhei. Da santa lá em baixo. Lá eu me agasalhei, lá eu ganhei o meu filho na rua. Sem comida, e sem uma peça de roupa. Porque ele nasceu de 7 meses. Quando essas pessoas vieram pra cá de barraca e contando a estória deles, que a casa tava quebrada, eu me juntei a eles, porque o que eu passei eu não quero que os outros passem... Que as pessoas vinham com a casa desmontada, casa quebrada, sem serviço, desempregado, umas pessoas muito revoltadas, né? Então aí eu me juntei a eles... A gente começou a fazer sopa, atender a comunidade. Aí eu comecei a trabalhar no papelão e criava filho, cuidava filhos das mães, pras mães trabalharem, né? E ali a gente foi indo, foi indo, foi indo, começamos a rezar debaixo da árvore. Debaixo de uma árvore nós começamos a rezar. Nessa reza que nós começamos a fazer, nós desse lado de cá não tinha santo, que do lado de lá tem a Nossa Sra. da Conceição, que é o lado sul da Ilha. E o lado Norte não tinha... Nós escolhemos a Nossa Senhora Aparecida e o Santo Antônio, foi a primeira Igreja que nós botemos. O Santo Antônio. Porque o Santo Antônio pra nós ele representa, dentro da religião umbanda, ele representa o Bará, né? Protetor das crianças. Aí nós botemos ele. Aí botemos a Nossa Senhora Aparecida. Aí começamos com a procissão, né? Começamos com a procissão por terra. Até tem algumas foto ainda daquela época. E sempre com aquela fé. Que a Nossa Sra Aparecida ela podia nos mostrar uma luz e uma vitória. ... A Igreja Católica ela é a Nossa Senhora Aparecida. Na Umbanda ela é a Nossa Senhora, a Nossa Mãe Oxum. Então aí eu lido com ela dos dois lados. Tanto do lado da Umbanda, quanto do lado da mãe Oxum, que ela vem do lado de Caboclo, né? Então a gente começou, começou a rezar, a pedir que ela estendesse o manto em cima da comunidade nas casas, nos lares, pra terminar com a miséria.... A gente não tinha nada, a gente bebia água do rio, né? A gente tomava água do rio, que era a água da mãe Oxum, né? Só que 
já tava ficando suja, tava ficando mal cuidada. Aí a gente começou a lutar, foi aonde a gente conseguiu a pipa. O carro pipa. As pessoas eram tudo com latinha de tinta, né? Porque não tinha tonel, não tinha latão, não tinha nada. Então a pipa a gente conseguiu botar dentro da associação, que aí era mais uma força que tinha, né? $\mathrm{E}$ dali a gente foi indo, foi indo, foi indo... A gente foi ensinando as mulheres a trabalhar. Aí se fundou as mulheres papeleiras, associação das mulheres papeleiras, né? Associação das mulheres papeleiras, as mulheres tavam trabalhando no galpão quando apareceu a nossa senhora aparecida, quebrada. E dali vem vindo a história. E eu acho assim que a procissão por água é a estória da água. Porque a água tem poder. A água salva mas a água também leva. A água é vida. A água, nós da religião, qual é as palavra que a gente pede: minha rica mãe. Assim como a tua água sagrada corre, então tu leva, todo peso que nós temos, todos os maus pensamentos que tem as crianças, que tem o jovem, que tem o sofrimento dessas famílias, então assim como a tua água corre tu há de correr todos esses maus fluídos..."

Quando lhe perguntei se as águas também não trariam o mal, em momentos de enchente, Nazaret respondia com as certezas da fé, que transformam a área de risco ${ }^{28}$ habitada na morada ideal, cosmicamente assentada nas suas relações com o mundo natural:

\section{Nazaret (Ilha Grande dos Marinheiros, 2003)}

"Sim, porque nós estamos no meio do rio, né? O rio arrodeia a ilha, né? E dentro da ilha tem o mato. ... Porque nós estamos em cima da água. A ilha tá em cima da água. E nós estamos em cima da água. $\mathrm{E}$ a gente sabe disso. Pra nós que somos de religião o dia mais feliz da nossa vida é quando vem enchente. Tu entendeu? Porque eu quando a enchente vem, e lava o meu pátio, é o ano mais feliz que eu sou. Por quê? Porque assim como ela lavou o pátio, a gente acende uma vela pra ela na porta e pede pra ela: Mãe. Todo mal, todo olho grande, toda inveja, que tiver dentro do meu lar você leva na sua água sagrada. Porque só a sua água que pode nos libertar. Então nós trabalhamos com a Natureza. É a força nossa é a Natureza."

A fala de Nazaret reconstrói com dignidade o esforço de fazer durar a vida coletiva dessa comunidade a que pertence, transformando a dimensão trágica do real vivido em marca identitária que apóia-se num saber construído a duras penas.

Os itinerários desses moradores, que acabam por conferir determinada identidade aos territórios das ilhas, estão portanto, profundamente ligados à memória

\footnotetext{
${ }^{28} \mathrm{O}$ termo área de risco refere-se a áreas no solo urbano que apresentam risco ao meio ambiente e à saúde, como encostas de morro que pode deslizar em enxurradas, brejos, charcos e ilhas que são ambiente de proliferação de epidemias, beiras de rio ocupadas que sofrem de erosão associada à enchentes. Todas estas áreas são sujeitas a impactos ambientais que em grande quantidade, e acumulados ao longo dos anos, são capazes de comprometer a renovação do lençol freático ou a qualidade de suas águas. (Ver capítulo 3).
} 
ambiental da Região Metropolitana de Porto Alegre, acompanhando muitas das transformações nas relações entre a cidade e os espaços alagadiços das ilhas. A comunidade de papeleiros, que ganha destaque nas políticas ambientais como a Romaria das Águas, acaba por converter em luta política por cidadania os espaços destinados à questão da proteção dos recursos hídricos.

Investigar esses itinerários nos possibilita compreender, no sentido da compreensão histórica proposta por Simmel (1984), uma causalidade formal (e não material) para o movimento desses grupos em tais áreas de margem e banhado, que embora não constituam territórios urbanos como bairros, ruas e praças das cidades, em seu aparente vazio comportam as aspirações e projetos (VELHO, 1981) dos diversos grupos no meio urbano.

O grande desafio do Delta do Jacuí é justamente regular essa ocupação que se dá a partir de tais projetos. Curiosamente, para estabelecer de fato a reserva ambiental nas ilhas, é preciso urbanizar o restante de seus territórios, levando em conta essa memória de enraizamento dessas famílias. As palavras de Nazaret, e de outros informantes, narrando sua trajetória social, entre rupturas, desenraizamentos e enraizamentos em diferentes territórios no Arquipélago e na margem oposta, em outros bairros de Porto Alegre, desenham formas sobre o mapa da região que mostram descontinuidades e continuidades, reviravoltas no ritmo do avanço do urbano sobre o verde. O mapa estático do planejamento urbano parece carecer de uma adesão aos movimentos dessas formas, pois as desconsidera. Conter o avanço da cidade cercando áreas, ou congelar os grupos atuais nos espaços do Delta parecem soluções muito distantes da forma como os itinerários dos grupos urbanos têm configurado os diferentes territórios da região.

Compreende-se, assim, como a santa dos papeleiros, converte-se em imagem das águas da Bacia Hidrográfica nas políticas ambientais. Neste evento, assim como em outras situações de conflito em que acompanhei (Devos, 2007) os moradores do Delta do Jacuí ao serem removidos das beiras dos rios, ao terem que lidar com a escassez do peixe, ao terem que suspender a criação de porcos e galinhas, ao negociarem o transporte e a venda de lixo reciclável nas ilhas, ao participarem de reuniões com o Poder Público, ao enfrentarem enchentes, é sobretudo o ambiente urbano sobreposto ao ecossistema do Delta do Jacuí que se revela. Importa aqui dizer que embora todos reconhecessem a importância da "Natureza” para a vida humana em geral, o ambiente ganhava nomes diversos, dependendo dos atores envolvidos no 
diálogo, na medida em que suas trajetórias pessoais estão mais ligadas às ilhas como suporte de suas redes de vizinhança e parentesco, ao Rio Guaíba como fronteira simbólica de sua inserção no meio urbano, enquanto que o Delta do Jacuí traz consigo a afirmação de um novo nome ao lugar, que incorpora todas essas instâncias do Poder Público como o Pró-Guaíba, e mesmo, a pesquisa científica, como esse trabalho acadêmico que não deixa de ser mais uma de muitas inserções de Universidades que voltam cada vez mais suas atenções para o Delta do Jacuí e suas riquezas.

É na mediação entre essa chamada ética planetária que toma o Planeta Terra como um mesmo ambiente comum a todos os seres humanos, e muitas éticas locais de apropriação dos ambientes que reside o desafio da preservação dos cursos de água e da promoção do acesso universal à água potável. Ao chavão ecológico da preservação do ambiente terrestre para os “nossos filhos” em um futuro provável, a questão do uso da água traz para o presente o fato de que já existe boa parte da população mundial sofrendo as conseqüências da contaminação e do esgotamento das fontes de água potável. Não se trata apenas da sobrevivência das gerações futuras, mas da coexistência com o Outro no presente. A grande contribuição dos chamados recicladores não é o de salvar grandes florestas do desmatamento, através da reciclagem do papel, mas o de refletir sobre as desigualdades na relação entre cidadania, moradia e saneamento urbano na baía de todas as águas.

\section{Referências:}

ANDERSON, B. Imagined communities. Londres: Verso, 1983.

APPADURAI, Arjun. Disjunção e diferença na economia global. FEATHERSTONE, Mike. Cultura Global. Petrópolis: Vozes, 1994, pp. 311-328.

BASSO, L. Bacias Hidrográficas do Rio Grande do Sul: implicações ambientais. In VERDUM, R.; BASSO, L.; SUERTEGARAY, D. Rio Grande do Sul - paisagens $e$ territórios em transformação. Porto Alegre: Editora da Universidade Federal do Rio Grande do Sul, 2004. pp.85-106.

DIEGUES, Antônio Carlos. O Mito Moderno da Natureza Intocada. São Paulo: NUPAUB-USP, 1994.

DIEGUES, Antônio Carlos. Etnoconservação. Novos rumos para a Conservação da Natureza. São Paulo: HUCITECH/NUPAUB-USP, 2000.

DURHAM, Eunice Ribeiro. A caminho da cidade : a vida rural e a migração para

São Paulo. 3. ed. São Paulo: Perspectiva, 1984.

DURKHEIM , Émile \& MAUSS, Marcel “Algumas formas primitivas de classificação” In: Durkheim (org. José Albertino Rodrigues), São Paulo: Ática, 1981.

ECKERT, Cornelia; ROCHA, Ana Luiza Carvalho. O Tempo e a Cidade. Porto Alegre: UFRGS, 2005.

ELIAS, N. O Processo Civilizador: formação do Estado e Civilização. RJ: Jorge Zahar Editor, 1994. 
FEATHERSTONE, Mike. Cultura Global. Petrópolis: Vozes, 1994.

FERRY, Luc. A nova ordem ecológica: a árvore, o animal e o homem. São Paulo: Ensaio, 1994.

FONSECA, Cláudia. Família, Fofoca e Honra - etnografia de gênero e violência em grupos populares. Porto Alegre: Editora da Universidade/UFRGS, 2000.

HALBWACHS, M. A Memória Coletiva. São Paulo: Vértice, 1990.

MAFFESOLI, M. No Fundo das Aparências. Petrópolis: Vozes, 1996.

MAUSS, M. Sociologia e Antropologia. São Paulo: Cosac \& Naify, 2003.

OLIVEIRA, R. C. e OLIVEIRA, L. R. C. Ensaios antropológicos sobre moral e ética. Rio de Janeiro: Tempo Brasileiro, 1996.

OLIVEN, R.G. A Parte e o Todo. A Diversidade Cultural no Brasil-Nação. Petrópolis: Vozes, 1992.

OLIVEN, R.G. Antropologia de Grupos Urbanos. Petrópolis: Vozes, 1995.

PARQUE ESTADUAL DELTA DO JACUÍ - PLANO BÁSICO. Vol. 1 - Porto Alegre: PMPA/SPM, 1979.

PORTO ALEGRE. Secretaria Municipal da Cultura. Centro de Pesquisa Histórica. Arquipélago: as ilhas de Porto Alegre. GOMES, José Juvenal; MACHADO, Helena Vitória dos Santos e VENTIMIGLIA, Marise Antunes. Porto Alegre: EU, 1995.

SAHLINS, M.Cultura e razão prática. Rio de Janeiro: Zahar, 2003.

SAHLINS, M. O pessimismo sentimental e a experiência etnográfica: por que a cultura não é um objeto em via de extinção. Mana, v. 3, n. 1, Rio de Janeiro: 1997.

SIMMEL, G. A Metrópole e a Vida Mental. In VELHO, O.(org.) O Fenômeno Urbano. Rio de Janeiro : Zahar, 1979.

SIMMEL, G. Les problèmes de la philosophie de l'Histoire. Paris: PUF, 1984.

SIMMEL, G. Philosophie de la Modernité. La femme, la ville, l'individualisme. Paris: Payot \& Rivages, 2004.

SOARES, Ana Paula. A Tutela da Água no Ordenamento Jurídico Brasileiro sob a Ótica da Lei 9.433/97 : Uma Questão Contemporânea. Monografia de conclusão do Curso de Ciências Jurídicas e Sociais da Pontifícia Universidade Católica do Rio Grande do Sul. Porto Alegre: 2003.

SOSNISKI, C. Repensando Fronteiras entre o lixo e o corpo: Estudo etnográfico sobre o Cotidiano de Recicladores, Catadores e Carroceiros na Ilha Grande dos Marinheiros. Porto Alegre: UFRGS, 2006. Dissertação (Mestrado) - Universidade Federal do Rio Grande do Sul. Instituto de Filosofia e Ciências Humanas. Programa de Pós-Graduação em Antropologia Social. 2006.

VELHO, G. Individualismo e Cultura: notas para uma antropologia das sociedades complexas. Rio de Janeiro: Zahar, 1981.

VELHO, O. O Fenômeno Urbano. Rio de Janeiro: Zahar, 1979.

VERDUM, R. O Ciclo do papel, da coleta ao processamento: personagens $e$ estrutura. In SUERTEGARAY, D.; BASSO, L.; VERDUM, R. Ambiente e lugar no urbano - a grande Porto Alegre. Porto Alegre: RS. Editora da Universidade Federal do Rio Grande do Sul, 2000. p. 187-204.

VERDUM, R.; BASSO, L.; SUERTEGARAY, D. Rio Grande do Sul - paisagens e territórios em transformação. Porto Alegre: RS. Editora da Universidade Federal do Rio Grande do Sul, 2004. 